\title{
KEPADATAN DAN FREKUENSI JENIS BURUNG PEMANGSA DI HUTAN GUNUNG EMPUNG, TOMOHON, SULAWESI UTARA
}

\author{
Nicky Kindangen ${ }^{1)}$ \\ ${ }^{1)}$ Program Studi Biologi FMIPA Universitas Sam Ratulangi, Manado 95115
}

\begin{abstract}
ABSTRAK
Tujuan penelitian ini adalah untuk menentukan kepadatan dan frekuensi jenis-jenis burung pemangsa yang hidup di hutan Gunung Empung, Tomohon, Sulawesi Utara. Penelitian ini dilaksanakan selama kurang lebih 2 bulan, yaitu dari awal bulan Oktober hingga akhir November 2010. Penelitian ini menggunakan metode Titik Hitung yang ditempatkan secara acak mulai dari ketinggian $1000 \mathrm{~m}$ di atas permukaan laut (dpl) hingga ke puncak gunung. Hasil penelitian menunjukkan bahwa di hutan Gunung Empung terdapat 3 jenis burung pemangsa, yaitu Accipiter griseiceps, Accipiter gularis dan Milvus migrans. Burung pemangsa dengan kepadatan tertinggi adalah Milvus migrans, sedangkan burung pemangsa dengan frekuensi kehadiran tertinggi adalah Accipiter gularis.
\end{abstract}

Kata kunci: burung pemangsa, frekuensi, kepadatan

\section{DENSITY AND FREQUENCY OF RAPTORS SPECIES AT MOUNT EMPUNG'S FOREST, TOMOHON, NORTH SULAWESI}

\begin{abstract}
The aim of this research was to determine the density and frequency of raptors at Mount Empung, Tomohon, North Sulawesi. This research was carried out for approximately 2 months, from early October until the end of November 2010. The method used for this research was Spot Count Method that was randomly placed from the altitude $1000 \mathrm{~m}$ above the sea surface to the top of the mount. The result showed that 3 species of raptors inhabited Empung's forest, i.e. Accipiter griseiceps, Accipiter gularis and Milvus migrans. Raptor with the highest density rate was Milvus migrans, whereas the most frequent raptor was Accipiter gularis.
\end{abstract}

Keywords: raptors, frequency, density

\section{PENDAHULUAN}

\section{Latar Belakang}

Burung merupakan salah satu hewan yang memiliki kaitan erat dengan kehidupan manusia sejak dahulu kala. Fungsi ekologis burung yaitu sebagai penyebar biji dan penyerbuk alami bagi tumbuhan sangat membantu petani dalam budidaya tanaman pangan. Burung juga dimanfaatkan manusia sebagai bahan makanan serta sebagai hewan peliharaan, bahkan burung juga turut berperan dalam berbagai budaya masyarakat. Burung dapat dijadikan sebagai indikator biologis berkaitan dengan kesehatan lingkungan serta sebagai tolak ukur kelestarian dalam pembangunan dan pemanfaatan sumber daya alam (Kinnaird,1997).
Burung adalah hewan yang memiliki kemampuan untuk terbang, berdarah panas atau eksotherm, tubuh ditutupi dengan bulu yang berwarna-warni. Mulut burung berupa paruh dengan berbagai bentuk yang sesuai dengan kegunaannya. Kulit kaki bagian bawah ditutupi oleh sisik, sementara extremitas anterior termodifikasi membentuk sayap dilengkapi dengan bulu-bulu yang berguna untuk terbang. Bulu-bulu tersebut sangat ringan karena tangkai bulunya berisi lubang hawa atau lubang udara dimana udara tersebut juga berfungsi sebagai penahan suhu tubuh. Paru-paru burung dilengkapi dengan kantong-kantong udara yang membantu menghasilkan energi lewat pernapasannya. Otot dada berfungsi untuk menggerakan sayap pada waktu terbang (Mahardono et al, 1980). 
Sulawesi Utara memiliki beragam habitat untuk penyebaran jenis-jenis burung. Salah satu tipe habitat itu adalah hutan pegunungan yang berada pada ketinggian lebih dari 800 meter dari permukaan laut (dpl) dengan karakternya yang unik. Beberapa jenis burung yang hidup di daerah ini tidak ditemukan di daratan rendah, serta beberapa jenis lainnya dari daerah yang lebih rendah sering menggunakan daerah ini di dalam wilayah jelajahnya.

Habitat merupakan suatu daerah yang dijadikan tempat tinggal dan beraktivitas bagi suatu jenis hewan. Hutan pegunungan merupakan suatu tipe habitat yang umum terdapat di Sulawesi Utara karena sebagian besar dataran daerah ini berupa gununggunung dengan ketinggian lebih dari $1000 \mathrm{~m}$ dpl. Hutan pegunungan memiliki beberapa ciri khas di antaranya adalah suhu yang lebih sejuk dibandingkan dengan hutan dataran rendah yang panas. Pepohonan lebih pendek dan kecil dengan epifit yang tumbuh di permukaan batang dan cabang-cabangnya. Di atas ketinggian $1500 \mathrm{~m}$, permukaan pohonpohon ditumbuhi lumut dan lumut kerak sehingga orang sering menyebut hutan yang seperti ini dengan nama hutan lumut (Kinnaird, 1997). Selain tajuk yang lebih rendah dan terbuka, hutan pegunungan memiliki keragaman komposisi jenis tumbuhan yang lebih rendah dibandingkan dengan hutan pamah (Coates dan Bishop, 2000).

Alikodra (1990) menyatakan bahwa satwa liar, termasuk burung di dalamnya, menggunakan tumbuh-tumbuhan sebagai sumber makanan serta sebagai tempat beristirahat dan tempat berlindung dari hujan atau panas.

Hutan pegunungan Sulawesi Utara merupakan habitat yang penting bagi keberadaan jenis burung, terutama jenis-jenis burung endemik Sulawesi (Coates dan Bishop, 2000). Hutan pegunungan menyediakan sumber pakan serta menjadi tempat berlindung yang aman bagi burung, sehingga mempengaruhi keanekaragaman jenis-jenis burung.

Jenis burung dan penyebarannya di daerah hutan pegunungan Sulawesi Utara belum diketahui dengan pasti. Hal ini disebabkan masih kurangnya perhatian yang khusus ditujukan untuk meneliti burung di hutan pegunungan. Oleh karena itu perlu dilakukan penelitian tentang keanekaragaman jenis burung yang hidup di hutan pegunungan dengan ketinggian daerah lebih dari $1000 \mathrm{~m}$ dpl, sehingga dapat melengkapi data mengenai kekayaan jenis burung di Sulawesi Utara.

\section{Tujuan Penelitian}

Tujuan dari penelitian ini adalah untuk menginventarisasi serta mengetahui kepadatan dan frekuensi jenis-jenis burung pemangsa yang hidup di hutan Gunung Empung, Tomohon, Sulawesi Utara.

Hasil dari penelitian ini diharapkan dapat memberikan informasi tentang jenisjenis burung diurnal yang hidup di hutan Gunung Empung, Tomohon, Sulawesi Utara, sehingga dapat dijadikan acuan untuk penelitian lebih lanjut serta membantu dalam upaya-upaya koservasi burung yang terancam populasinya.

\section{METODOLOGI PENELITIAN}

\section{Waktu dan Tempat Penelitian}

Penelitian ini dilaksanakan selama bulan September-Oktober 2010, dan bertempat di hutan Gunung Empung, Kota Tomohon, Sulawesi Utara dengan lokasi pengambilan data pada ketinggian $1000 \mathrm{~m}$ dpl sampai ke puncak gunung.

\section{Bahan dan Alat Penelitian}

Objek penelitian ini adalah burungburung pemangsa (raptors) yang ada di hutan Gunung Empung. Alat yang digunakan dalam penelitian ini adalah: Binokuler merk Super Zenith dengan pembesaran $7 \times 50 \mathrm{~mm}$, alat tulis-menulis dan buku catatan, Global Positioning System, Kompas dan Peta, serta Buku Panduan Lapangan Burung-burung di Kawasan Wallacea karya Coates dan Bishop, 2000

\section{Metode Pengambilan Data}

Metode yang digunakan untuk penelitian ini adalah metode titik hitung, dimana metode ini lebih sesuai digunakan untuk melakukan survey yang tidak banyak berpindah, dan juga lebih mungkin untuk dilakukan ditempat yang vegetasi pohonnya rapat. Metode ini memungkinkan untuk 
mencatat lebih banyak jenis burung, terlebih untuk burung-burung yang bersifat kriptis (suka bersembunyi atau berdiam diri). Titik hitung ditempatkan secara acak dalam lokasi penelitian sehingga dapat mewakili keseluruhan lokasi tersebut. di daerah yang kepadatan burungnya rendah, cara mengatasinya adalah bukan menambah periode penghitungan tetapi menambah jumlah stasiun survey (Bibby et al, 2000). Variabel yang diamati pada waktu penelitian diantaranya: Jenis burung, Jumlah burung, serta Ketinggian tempat.

Pengamat berdiri dalam satu lokasi yang telah ditetapkan (sebuah stasiun sensus) selama periode waktu tertentu dan mencatat ciri-ciri dan jenis burung yang teramati, jumlah individu tiap jenis, ketinggian tempat serta kondisi umum habitat di lokasi tersebut, dalam radius $20 \mathrm{~m}$ dari titik pusat. Lama periode pengamatan di setiap titik adalah 10 menit.

Titik-titik hitung ditempatkan mulai dari ketinggian $1000 \mathrm{~m}$ dpl sampai ke puncak gunung, dan dilakukan secara acak namun dapat mewakili keseluruhan daerah penelitian di gunung tersebut. Identifikasi jenis burung dilakukan dengan cara mengamati ciri yang khas dari burung tersebut, kemudian mencocokkannya dengan gambar dan deskripsi dalam buku Panduan Lapangan Burung-burung di Kawasan Wallacea, oleh Coates dan Bishop (2000).

Cara mengamati dan mengidentifikasi jenis burung yaitu dengan melihat dan mencatat tanda-tanda khusus pada burung yang diamati. Tanda-tanda yang utama seperti bentuk paruh, ekor, kaki dan warna bulu. Tingkah laku dapat juga dijadikan dasar untuk mengenali suatu jenis burung (Iskandar, 1989).

\section{Analisis Data}

Setelah data diperoleh, dihitung frekuensi dan kepadatan (densitas) dari masing-masing spesies. Frekuensi dihitung berdasarkan jumlah kemunculan spesies dalam keseluruhan titik hitung, dengan kata lain berapa kali atau dalam berapa titik suatu spesies muncul dari total titik yang diamati (Michael, 1995). Secara sederhana frekuensi dapat ditulis dalam rumus :

$\mathrm{F}=\frac{\text { Jumlah titik yang terdapat spesies A }}{\text { Jumlah seluruh titik yang diamati }} \times 100 \%$
Sedangkan densitas adalah: kerapatan atau jumlah cacah individu suatu spesies per satuan luas. Rumus densitas dapat ditulis sebagai berikut:

$\mathrm{D}=\frac{\text { Jumlah individu suatu spesies }}{\text { Luas daerah yang diamati }}$

\section{HASIL DAN PEMBAHASAN}

Burung pemangsa (Raptor) memiliki tipe paruh penusuk dan pengoyak (Piercing and Tearing Type). Paruh tipe ini memiliki ciri-ciri berukuran pendek, tebal dan kokoh, meruncing, ujung paruh atas agak berbentuk seperti kait, serta bertepi tajam. Tipe paruh ini teradaptasi untuk menusuk dan mengoyak daging mangsanya (Verma, 1997). Setelah dilakukan pengamatan, burung pemangsa yang hidup di hutan Gunung Empung terdiri 3 jenis yaitu:

\section{Accipiter griseiceps (Elang-alap Kepala- kelabu/Sulawesi Goshawk)}

Merupakan salah satu jenis burung pemangsa yang penyebarannya endemik di sub-kawasan Sulawesi, Kepulauan Togian, Muna dan Butung. Menghuni hutan pamah, hutan perbukitan dan hutan pegunungan, juga mangrove; dari permukaan laut sampai ketinggian $2200 \mathrm{~m}$ (Coates dan Bishop, 2000). Di hutan Gunung Empung ditemukan sekali pada ketinggian $1020 \mathrm{~m} \mathrm{dpl}$, dengan densitas 10 individu $/ \mathrm{km}^{2}$ dan frekuensi $0.9615 \%$.

Ciri-ciri burung ini adalah: mahkota dan wajah berwarna abu-abu tua, tidak berjambul. Punggung coklat tua, mesial bercoret gelap, dada dan bagian perut bercoret tebal coklat tua, paha berpalang. Pada individu immature (remaja atau belum dewasa kelamin) bagian kepala berwarna coklat, coretan pada bagian dada dan perut berwarna merah karat, serta garis-garis berpalang pada paha lebih tebal (Coates dan Bishop, 2000; White and Bruce, 1986).

\section{Accipiter gularis (Elang-alap Nipon/Japanese Sparrow-hawk)}

Merupakan jenis burung pemangsa migran (visitors) selama musim dingin di daerah utara (Oktober-April). Sering 
mengunjungi tepi hutan, hutan sekunder dan lahan budidaya berpohon jarang. Ditemukan dari permukaan laut sampai ketinggian 1600 m (Coates dan Bishop, 2000). Di Gunung Empung burung ini teramati pada ketinggian 1160-1200 $\mathrm{m}$ dpl, dengan densitas 20 individu $/ \mathrm{km}^{2}$ dan frekuensi $2.8846 \%$.

Ciri-ciri burung ini adalah: pada individu jantan tubuh bagian atas (dorsal) berwarna abu-abu, dada dan perut berpalang merah-karat pucat, serta setrip mesial tipis. Pada individu betina, tubuh bagian atas coklat tua (bukan abu-abu), dada dan perut berpalang coklat. Pada individu remaja dada bercoret merah-karat. Semua individu mempunyai ekor berwarna abu-abu dengan beberapa palang gelap (Coates dan Bishop, 2000; Prawiradilaga et al, 2002).

\section{Milvus migrans (Elang Paria/Black Kite)}

Jenis burung pemangsa yang merupakan penetap (resident). Sering dijumpai di pedesaan yang terbuka dengan pohon-pohon yang jarang dan terpencar, di danau, rawa-rawa, kota-kota pesisir serta pelabuhan, dari permukaan laut sampai ketinggian 1100 m (Coates dan Bishop, 2000; White and Bruce, 1986). Di hutan pegunungan Gunung Empung, burung ini tercatat pada ketinggian $1020 \mathrm{~m} \mathrm{dpl}$, dengan densitas 40 individu $/ \mathrm{km}^{2}$ dan frekuensi $1.9231 \%$.

Ciri-ciri dari burung ini adalah: tubuh berwarna coklat dengan bagian kepala yang berwarna agak lebih pucat dan terdapat bercak putih pucat di bagian bawah sayapnya. Ciri khas yang membedakan jenis elang ini dengan jenis-jenis elang lainnya adalah ekornya yang bercabang (menggarpu) (Coates dan Bishop, 2000; Holmes dan Phillips, 1999; Verma, 1997).

\section{Kepadatan dan Frekuensi}

Kepadatan atau Densitas adalah banyaknya individu yang hidup dalam suatu satuan luas tertentu. Dari hasil pengamatan, spesies burung pemangsa dengan densitas tertinggi adalah Milvus migrans yaitu 40 individu $/ \mathrm{km}^{2}$, kemudian diikuti oleh Accipiter gularis yaitu 20 individu $/ \mathrm{km}^{2}$ dan spesies dengan densitas terendah adalah Accipiter griseiceps yaitu 10 individu $/ \mathrm{km}^{2}$.
Frekuensi menyatakan seberapa seringnya suatu spesies dijumpai pada suatu lokasi. Dengan kata lain frekuensi bisa juga dianggap sebagai seberapa besar peluang suatu spesies untuk dijumpai pada daerah tersebut. Dari hasil pengamatan, spesies Accipiter gularis merupakan jenis burung pemangsa yang paling sering dijumpai selama penelitian, dengan frekuensi sebesar $2.8846 \%$, kemudian disusul Milvus migrans dengan persentase kehadiran sebesar $1.9231 \%$ dan spesies yang paling jarang dijumpai adalah Accipiter griseiceps dengan frekuensi sebesar $0.9615 \%$.

\section{Deskripsi Umum Habitat}

Gunung Empung terletak di Kota Tomohon, Sulawesi Utara. Variasi habitat di Gunung Empung cukup beragam, mulai dari daerah perkebunan di kaki gunung yang berbatasan dengan hutan, hutan pegunungan dengan sedikit daerah hutan yang terbuka hingga, alang-alang yang berada di bagian puncak gunung. Habitat yang beragam ini menunjang kehidupan berbagai jenis burung, termasuk juga burung pemangsa. Dari 3 jenis burung pemangsa yang ditemukan, 1 jenis adalah "Endemik" Sulawesi yaitu hanya ditemukan di Sulawesi. Karena itu kelestarian hutan Gunung Empung sebagai habitat dari burung-burung endemik Sulawesi perlu ditingkatkan.

\section{KESIMPULAN}

Terdapat 3 jenis burung pemangsa (raptors) yang hidup di hutan Gunung Empung, Tomohon, Sulawesi Utara. Ketiga jenis burung pemangsa tersebut adalah Accipiter griseiceps yang merupakan hewan endemik Sulawesi, Accipiter gularis dan Milvus migrans. Burung pemangsa dengan kepadatan tertinggi adalah Milvus migrans dengan 40 individu $/ \mathrm{km}^{2}$, kemudian Accipiter gularis (20 individu/ $\left.\mathrm{km}^{2}\right)$ dan Accipiter griseiceps $\left(10\right.$ individu $\left./ \mathrm{km}^{2}\right)$. Sedangkan burung pemangsa dengan frekuensi tertinggi adalah Accipiter gularis dengan persentase kehadiran $2.8846 \%$, disusul Milvus migrans $(1.9231 \%)$ dan Accipiter griseiceps $(0.9615 \%)$. 


\section{DAFTAR PUSTAKA}

Alikodra, H. S. 1990. Pengelolaan Satwa Liar. Jilid I. Institut Pertanian Bogor.

Bibby, C., M. Jones dan S. Marsden. 2000. Teknik-teknik Ekspedisi Lapangan: Survey Burung. Terjemahan S.N.Kartikasari dan Jeni Shannas. Bird Life International-Indonesia Programme. Bogor.

Coates, B. J. dan K. D. Bishop. 2000. Panduan Lapangan Burung-burung di Kawasan Wallaceae. Penerbit Bird Life Indonesia. Bogor.

Holmes, D. dan K. Phillips. 1999. Burungburung di Sulawesi. Bird Life International-Indonesia Programme. Puslitbang Biologi-LIPI. Bogor.

Iskandar, J. 1989. Jenis Burung Yang Umum di Indonesia. Penerbit Djambatan. Jakarta.

Kinnaird, F. M. 1997. Sulawesi Utara : Sebuah Panduan Sejarah Alam. Yayasan Pengembangan Wallacea Indonesia.
Mahardono, A., S. Pratignyo, S. Iskandar. 1980. Anatomi Burung. Penerbit Intermasa, Jakarta.

Michael, P. 1995. Metode Ekologi Untuk Penyelidikan Ladang dan Laboratorium. UI-Press. Jakarta.

Prawiradilaga, D. M., T. Muratte, A. Muzakkir, T. Inoue, Kuswandono, A. A. Supriatna, D. Ekawati, M. Y. Afianto, Hapsoro, T. Ozawa dan N. Sakaguchi. 2002. Panduan Survey Lapangan dan Pemantauan Burungburung Pemangsa. Biodiversity Conservation Project-JICA.

White, C. M. N. and M. D. Bruce. 1986. The Birds of Wallacea (Sulawesi, The Moluccas and Lesser Sunda Islands, Indonesia). British Ornithologists Union. London.

Verma, P. S. 1997. A Manual of Practical Zoology Chordates. S. Chand and Company Ltd. New Delhi. 